Revue bibliographique pour le domaine irano-aryen

Volume 32-33 | 2013

Comptes rendus des publications de 2009-2010

\title{
Mathieu Terrier. Le Maḥbûb al-qulûb de Quṭb al-Dîn Ashkevarî : Une œuvre méconnue dans l'histoire de l'histoire de la sagesse en islam
}

\section{Andrew Newman}

\section{(2) OpenEdition \\ 1 Journals}

\section{Electronic version}

URL: http://journals.openedition.org/abstractairanica/40541

DOI: 10.4000/abstractairanica.40541

ISSN: 1961-960X

Publisher:

CNRS (UMR 7528 Mondes iraniens et indiens), Éditions de l'IFRI

\section{Printed version}

Date of publication: 1 December 2013

ISSN: 0240-8910

\section{Electronic reference}

Andrew Newman, « Mathieu Terrier. Le Mahbûb al-qulûb de Qutb al-Dîn Ashkevarî : Une œuvre méconnue dans l'histoire de l'histoire de la sagesse en islam », Abstracta Iranica [Online], Volume 32-33 | 2013, document 392, Online since 01 July 2016, connection on 05 October 2020. URL : http:// journals.openedition.org/abstractairanica/40541; DOI : https://doi.org/10.4000/abstractairanica. 40541

This text was automatically generated on 5 October 2020.

Tous droits réservés 


\title{
Mathieu Terrier. Le Mạ̣bûb al-qulûb de Quṭb al-Dîn Ashkevarî : Une œuvre méconnue dans l'histoire de l'histoire de la sagesse en islam
}

\author{
Andrew Newman
}

\section{REFERENCES}

Mathieu Terrier. « Le Maḥbûb al-qulûb de Quṭb al-Dîn Ashkevarî : Une œuvre méconnue dans l'histoire de l'histoire de la sagesse en islam ». Journal Asiatique, vol. 298/2, 2010, p. 345-387.

1 The author addresses this important, but till now little-known, work on the history of wisdom composed during the later Safavid period by Aškevarī (d. between 1088/1677 and 1095/1684), šayH al-Islām, in Lāhijjān province. This history starts with the first sage, Adam, and advances till the Safavid period, to the well-known scholar of the Isfahan School of Philosophy, Mīr Dāmād (d. 1041/1631-2). Terrier argues that the text should be understood as not only a history but also a contribution to a discourse on the history of the history of wisdom itself. Texts on wisdom in the Arab-Muslim tradition encompass works of this genre as well as bibliographies, collections of sayings and even heresiographies. All of these, Terrier suggests, address the common theme of the transmission of "foreign knowledge" (Greek, Egyptian, Persian and Indian, for example) and its integration into the Islamic tradition of al-hikma. As a genre, these texts suffer from a variety of problems, such as repetition or their having been commissioned by rulers.

2 The author reviews, in detail, the authorities and sources used by the author of the original text. The earliest Arabic materials date from the eighth and ninth centuries in Baghdad and from the tenth and eleventh centuries in Andalusia. They include texts 
translated from Greek and Christian originals, as well as 8th century texts in the sciences. Terrier then discusses elements of comparative philosophy that can be detected in the history of wisdom, such as references to the "nation" (understood in relation to climate, geography and language).

3 Terrier describes the text itself, its composition and sections. The first reviews major figures in the history of wisdom from Adam to the years immediately preceding the emergence of Islam. The second focuses on the eminent sages of Islam, their ideas and writings. The third discusses the Imams, major figures in the Twelver Shiite scholarly tradition and Mīr Dāmād. Terrier comments on some of the persons mentioned in the history of wisdom and discusses the larger framework of this text. Its second section was, he suggests, of special importance since it was written in what he calls the "antiintellectual" climate under the reign of the Safavid ruler Šāh Sulaymān (1666-1694). Among the people mentioned in the third section are, as Terrier points out, persons who are usually considered not to be philosophers per se but, instead, "traditionists" or "jurists".

4 This work rightly holds an important place in our understanding of Islamic thought and of how Muslim scholars viewed their precursors.

\section{AUTHORS}

\section{ANDREW NEWMAN}

Université d'Edimbourg 